\title{
Micah's shepherd-king (Mi 2:12-13): An ethical model for reversing oppression in leadership praxis
}

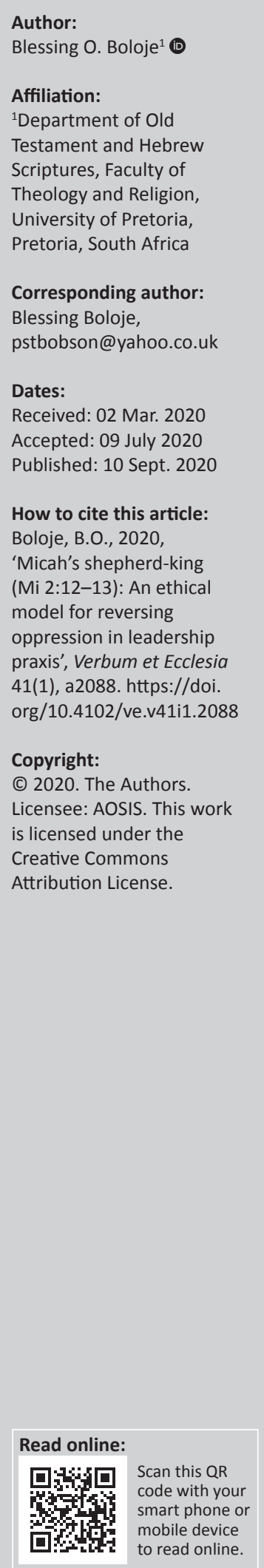

The exposition attempts to use Micah's metaphor of shepherd-king (Mi 2:12-13) as a heuristic ethical model for reversing oppression and violence in leadership praxis. Given the reality of widespread oppression and violence perpetrated by the powerful, Micah 2:12-13 is interjected into the oracle as a means of accentuating the hope of those who are marginalised and dispossessed. Although Micah's shepherd-king metaphor interrupts the foregoing context of the oracle of condemnation and doom, the unit logically balances the general rhetorical pattern of judgement, and afterward salvation. Such a canonical and ideological reading presents a window through which informed ethical models are constructed for the reversal of oppression and violence in the readers' socio-economic and religious context. Micah's shepherd-king metaphor imagines a restoration of fortune under the leadership of a coming eschatological shepherd-leader allows one a positive construct of a visionary leader, who is a passionate agent of restoration rather than one who is an agent of exploitation, oppression and bondage.

Intradisciplinary and/or interdisciplinary implications: As a rhetorical literary production, there are seemingly noteworthy ideological and theological intentions in the Book of Micah. Consequently, this exposition brings together biblical, literary, exegetical and theological discourses into dialogue with ethics, ethical demands and practical theology. Granted that leadership affects every aspect of community life, Micah's beautifully harmonised, biblical shepherd-king in time and context generates insightful alternative and viable components of the process of conveying its life-giving and instructive power for contemporary leadership praxis, both within the ecclesia community and larger human society.

Keywords: Micah; shepherd-king; flock; leadership; oppression and violence; ethical model; reversal of fortune.

\section{Introduction}

Shepherd-king metaphor applies generally to deities and human leaders both within the ancient Near East (ANE) and the Hebrew Bible/Old Testament (HB/OT) (cf. Varhaug 2019:16). In the ANE, it seems that the shepherd-king metaphor develops from its geographical and agricultural setting, where the knowledge of the relationship between shepherd and sheep is well established (cf. Pritchard 1975:177-178; Taylor 1983:7). Kings and gods are described repeatedly as shepherds because of their ruling position. Consequently, kingship is grounded in the portrayal of rulership as typified in the imagery of a shepherd. Similarly, to speak of Yahweh specifically as a shepherd is to speak of Yahweh's kingship and his kingdom (Chae 2006:19-20; cf. Joyce 1998:323-337). Within the context of Assyrian government (Deijl 2008):

$[T]$ he king was seen as a shepherd of his subjects, the keeper of their well-being and welfare. Yet, it was the god Ashur, not the king who stood at the top of the pyramid. (p. 34)

Every act of disloyalty to the king invariably and automatically implies an act of disloyalty to the god, Ashur (Deijl 2008:34). Whilst the Assyrian king Shalmaneser I (ca. 1280 BCE) is addressed as 'shepherd', the Egyptian king Amenhotep III (1411-1374 BCE) is addressed as 'shepherd', who supposedly operates in a close relationship with a deity, with whom he shared authority (cf. Bosetti 1993:12). Thus, he is seen as 'the good shepherd, vigilant for all the people, whom the maker thereof has placed his authority, lord of plenty' (Chae 2006:21). As an ideal king, his hallmark is seen in the quality of time that he spent in caring for his subjects (Pritchard 1975:441). This ANE shepherd-king metaphor imagines and designates kings as shepherds, who exist for the benefit of their followers. Their status implies responsibility rather than rights, entitlements and power. The shepherd-king is to serve and provide for their subjects by ensuring that justice is properly 
administered and exploitation, oppression and violence are avoided (Wright 2004:126-127).

Biblical writers, and in particular the HB/OT, picked up this metaphor and applied it to Yahweh. It is widely articulated around the period immediately before, during and after exile. The figure of speech is extensive in the Psalter as well as in consoling prophetic oracles of the exile. Those who occupied an essential leadership position, such as kings, judges, rulers and priests, were regarded as shepherds in terms of their responsibility and the quality of service that they rendered to their subjects (Keil \& Delitzch 1955:80-84). Although leaders of Israel are addressed as shepherds by Yahweh (cf. $2 \mathrm{Sm} \mathrm{7:7;} 1 \mathrm{Ki}$ 22:17; 1 Chr 17:6; Is 63:11; Jr 22:22; 23:2, 4; Ezk 34:2, 7), shepherd metaphor is reserved exclusively for Yahweh until the inception of the monarchy in Israel (Chae 2006:26). In the Exodus and Desert narratives, Yahweh's image as a shepherd is seen in his faithful leadership of his flock to fruitful and safe pastures (Ex 15:13, 17; cf. Ps 78:52-55, 71-72). In Jeremiah's oracle, the prophet describes Yahweh's shepherd quality: '[h]e who scattered Israel will gather him, and keep him as a shepherd keeps his flock' (Jr 31:10; cf. Stewart 1996:1093). In his interpretation of the title, Mays (1976) remarks that:

The title 'shepherd' belongs to YHWH's identity as ruler of his people. The role of shepherd became prominent especially in exilic salvation prophecy when the predicament of the dispersion appeared to offer no future beyond the dissolution of Israel among the nations (e.g., Jr 23:3; 31:8-10; Is 40:11; Ezk 34). (p. 75)

Micah's oracle introduces the coming eschatological shepherdking, a metaphor that serves as a restoration motif and that ignites peace for the people of Israel and/or Judah, as Yahweh's flock (Chae 2006:37). In the following sections, the central focus of this investigation is that of evaluating the literary and theological implications of shepherd-king metaphor, and that of the people of Israel and/or Judah, as Yahweh's sheep. This exploration is done against a background of the oppression which Micah witnessed, as represented in the literary prophetic text. Clearly, Micah's shepherd-king metaphor imagines a restoration of fortune under the leadership of a coming eschatological shepherd. From a canonical perspective, the exegetical analysis and development of the metaphor allows for the deduction of ethical models for reversing the dimensions of oppression and violence in leadership praxis where protection, care and sustenance are discovered to be lost in the Book of Micah. Consequently, Micah's shepherd-king metaphor obviously stimulates as well as provides a viable alternative for contemporary leadership reflection.

\section{Literary setting of Micah 2:12-13}

Micah 2:12-13 is seen as an enigmatic passage in the Book of Micah (Mays 1976:74; Sweeney 2014:263). The presence of catchword and thematic strand reflected in the oracle of salvation in Micah 4:6-7 has given rise to the interpretation of the verses (2:12-13) by some scholars as a later editorial addition, accidentally transposed into Micah's authentic words (Sweeney 2014:263; cf. Hillers 1984:38-39). Although Micah's shepherd-king metaphor interrupts the foregoing context of the oracle of condemnation and doom (Hillers 1984:38), Micah 2:12-13 is traditionally understood as an oracle of salvation (Ben Zvi 2000:52; McKane 1998:87-94; Mignon 2001:115-117; Wagenaar 2001:230-240). In his interpretative explanation, Nogalski (2011:540) notes that significant discussion exists in recent years with respect to how the imagery in these two verses is to be interpreted - 'whether it depicts a threat or a promise'. What creates a sense of balance is:

[T] he idea of Yahweh gathering sheep, like a flock in a pasture when that flock represents a remnant of Israel led by $\mathrm{YHWH}-$ makes more sense as an image of deliverance than as judgement. (Nogalski 2011:540)

The similarity of Micah 2:12-13 in terms of the language and imagery used in the description of Yahweh in Micah 4:6-7 has given rise to the interpretation of the verses:

... [A]s a particular version of the drama of salvation proclaimed by Deutero-Isaiah in which YHWH as King (Is 41:21) gathers his flock (40:11; 43:5f), overwhelm [sic] their enemies (41:15f.; 45:2), and leads the liberated people in a new exodus (49:9ff.; 51:10). (Mays 1976:74; cf. Shaw 1993:88)

Generally, the materials in Micah 2 are treated as three relatively autonomous units, namely, social ethics, divine judgement and divine hope (Mi 2:1-5); social ethics, divine character and patronship, distorted theological positions and judgement (Mi 2:6-11); and the announcement of future salvation (Mi 2:12-13) (Ben Zvi 2000:41-70; cf. Andersen \& Freedman 2000:253-343; Hillers 1984:31-40; Wagenaar 2001:208-240; Wolff 1990:72-74). Micah 2:12-13 functions in a similar manner at a redemptive structural level, as it takes up the threat of oppression, dispossession and exile (the downfall of Judah) developed in the previous units, against a group of individuals who violate ethical standards in the covenant community of Judah (Dempster 2017:80; Sweeney 1996:529, 2000:357; Westermann 1991:142). The verses are interpreted as a response to the theme of the first macrosection of the Book Micah (1:2-2:13), which indicates that the consequences of injustice will affect the environment and geography of the people (Cuffey 2015:226).

The unit does not only imply and imagine that the misfortune and downfall of Judah have already happened, but announces an eschatological future in which Yahweh will undoubtedly gather Jacob (Ben Zvi 2000:65). As a consequence, Ben Zvi (2000:69) remarks that the unit provides a bridge between the idea of the anticipated status of Israel and/or Judah in view of their relationship to Yahweh - their king, leader and patron - and the fate of monarchic Israel and/or Judah on the one hand and the status of the post-monarchic community of readers of the book on the other hand. Micah 2:12-13 cannot be seen as either the words of optimistic false prophecy (cf. Dempster 2017:104; Jenson 2008:128) or later interpolation (cf. Sweeney 2014:263), but an integral part of the discourse of Micah 2-3. According to Andersen and Freedman (2000:343), a contrary reading will result in missing 'the complexity of the paradoxical, ambivalent, dialectical relationship between 
Yahweh and Israel in the ongoing covenant (at once conditional and unconditional) as it was appreciated by the classical prophets'.

The setting of surrounding materials in previous units is relatively fixed somewhere in the larger scope of time in the world of the book, indicated in the superscription - an 8thcentury context Mi 1:1 (Andersen \& Freedman 2000:17-20; Ben Zvi 2000:63; Coomber 2011:396-432; Kaiser 1998:352; McKeating 1971:162; Walton, Matthews \& Chavalas 2000:780-781). However, the openness and ambiguity of Micah 2:12-13 make it difficult to determine its precise historical setting and authorship with certainty. There is no precise information or historical setting of the reading and re-reading of the speech of the speaker in the world of the book (Ben Zvi 2000:69). The implied author of the text does not suggest that the intended readers approach the text from a perspective informed by any set of historical narratives or circumstances. Quite commonly, the only historical circumstances that can be imagined are obviously put in the future of the speaker, taken to be exilic and postexilic situation (Hillers 1984:39), which 'from the vantage point of the post-monarchic readers and post-monarchic discourse in general, was most likely associated with the fall of monarchic Judah' (Ben Zvi 2000:69).

Although there is no unanimity of opinion regarding the origin of Micah 2:12-13 (cf. Andersen \& Freedman 2000:332), the unit echoes a note of hope quite different from neighbouring materials, and fits most precisely the exilic or post-exilic circumstances of the people of Israel and/or Judah who had been decimated and scattered by the Assyrian and Babylonian invasions, conquests and deportations that brought to an end the monarchies of both kingdoms (Andersen \& Freedman 2000:332). This particular and ideological reading allows the readers to find a word of hope for those who have suffered exploitation, oppression, violence and the great judgement of the Babylonian exile. Similarly, the message would have been equally relevant in earlier times, including Micah's time (Jenson 2008:128), and most importantly, the message looks towards the community or communities of readers of the book (Ben Zvi 2000:69).

\section{Micah's shepherd-king and his flock (Mi 2:12-13)}

Micah 2:12-13 is the shortest oracle unit in the first macrosection of the Book of Micah (1:2-2:13), and the first manifestation of Yahweh's mercy, following adjoining units of judgement speeches. It begins with an announcement of Yahweh's decisive action in the first-person and ends with the repetition of similar astonishing breakthrough. The divine announcement is made in view of what has been happening in concise but electrifying manner. The oracle depicts Yahweh, first in terms of a shepherd (2:12) and then as a king (2:13). The text and a progressive exegetical analysis of the shepherd-king metaphor are as presented here:
NASB 2:12 I will surely assemble all of you, Jacob,

I will surely gather the remnant of Israel.

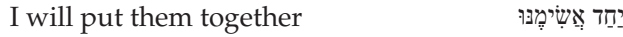

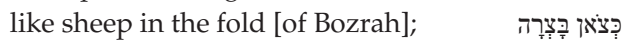

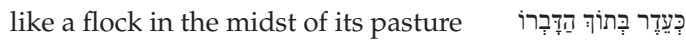

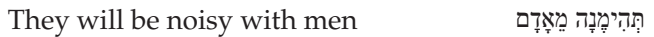

2:13 The breaker goes up before them; 2:13 they break out [through]

pass through the gate,

and go out by it

So their king goes on before them

and the LORD at their head

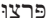

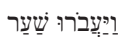

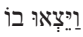

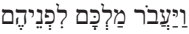

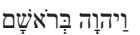

\section{The shepherd flock (Mi 2:12)}

Micah 2:12 begins with the announcement of divine actions. These actions are presented in growing and intensifying suspense and concluded with a divine epiphany (Dempster 2017:99). Although the reason for the change of speaker is not indicated (Andersen \& Freedman 2000:337), God speaks through the prophet by assuming the role of the shepherd in verse 12. As the shepherd of Israel, Micah 2:12 employs two parallel phrases - אָסף אֶָס [I will surely gather] and

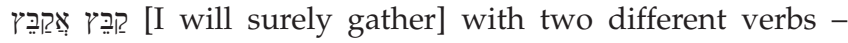

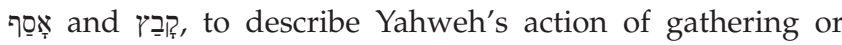
assembling Israel. Each verb is characteristically doubled in the emphatic construction and the synonymous pair further reinforces the certainty of the promised action of Yahweh (Jenson 2008:129). ${ }^{1}$ The announcement of hope, which is a fittingly dramatic contrast to the long section of judgement that precedes it, indicates that the promises of hope and salvation lie alone in the possibility that the shepherd metaphor or title represented a dimension of Yahweh, which transcended his wrath and judgement (Dempster 2017:101; Jenson 2008:129; Mays 1976:75).

The corresponding names Jacob/Israel, in chiastic parallelism

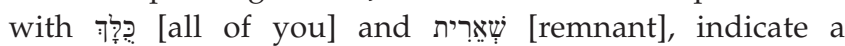
collective idea that situates the names in the vocative. Such an analysis would imply that the entire scattered remnant of the people will be gathered and restored. The image of a shepherd gathering together the remnant of his scattered flock, after a severe disaster and/or judgement (Dempster 2017:101), is not to be viewed as a 'mass repatriation of deported prisoners' (Andersen \& Freedman 2000:337), but rather as an indication of the possibility of survival and hope, even in the face of an inevitable judgement. This gathering together, according to Andersen and Freedman (2000:337), 'matches the cycle of ill and good fortune that biblical historians found throughout Yahweh's dealing with Israel' $^{\prime 2}$ This gathering of scattered flock will re-establish Jacob as a community, once again.

1.According to Edward (2015:75), "[t] he emphatic construction "When lakob is gathered together he will be gathered together" is the LXX rendering of a Hebrew infinitive absolute plus a finite verb, and the passive voice combined with the repetition of the verb serves to further emphasise the action of the gathering together'.

2.For other prophetic books with similar expressions with a clear implication of return from exile, see Jeremiah 23:3 and Zephaniah 3:19. 
The remnant or survivor theme is expounded by the well-

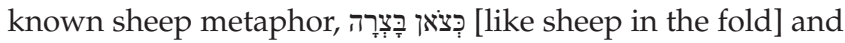

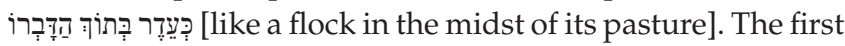
expression is literally translated as 'sheep of Bozrah' (Jenson 2008:129). In the Bible, three towns are known by the name of Bozrah: one is a city of Moab (Jr 48:24, although the text is not clear), a location in the Hauran, south of Damascus (1 Mac 5:26-28) and a city in Edom, an ancient seat of government (Gn 36:33). Bozrah is noted to be a shearing centre, like Timnah (Gn 38) or Karmel (1 Sm 25), and it is mentioned by other prophets (Is 34:6; 63:1; Am 1:12). The presence of the image in the text could have been to invoke memories of the original divine shepherding of Israel from the land of Edom into Canaan after the Exodus' (Andersen \& Freedman 2000:337). Jenson (2008:129) observes that ' $[a]$ closely related form of the word means "encampment" (Gn 25:16), perhaps used to emphasise the human target of the metaphor'.3

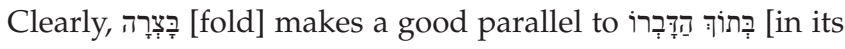
pasture], and the similes of 'fold' and 'pasture' are taken as literal references to 'the quality or quantity of the flock (cf. Is 60:7; Amos 4:1; also cf. the connotation of "plenty" in Ezk 36:37-38; Ps 107:41)' (Ben Zvi 2000:66).

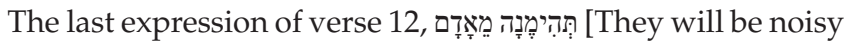
with men], although obscure, is literally translated as, 'they [the gathered sheep] will be noisy from men' (Dempster

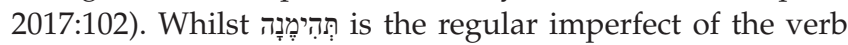
[Tֵַ [make noise, an uproar], which describes the noise made by a crowd (cf. Isa 17:12) (Andersen \& Freedman 2000:340), the preposition מאָזָדם [from man] is baffling as it assumes different meanings. It could be spatial and implies separation that is far away from human beings (Jenson 2008:130). It could have a causal meaning, with two possibilities, namely, because of someone or people who threaten the flock or because of such crowd of people gathered in one place (Allen 1976:300; Andersen \& Freedman 2000:340; Mays 1976:75). As the metaphor has changed from sheep to people, it is in all probability a reference to the abundance of the population and the highly emotional uproar of the people, resulting from their being gathered into one place by the good shepherd (i.e. Yahweh) who leads them to safety (cf. Ben Zvi 2000:66; Dempster 2017:102).

\section{The breach maker-king (Mi 2:13)}

The first phrase of Micah 2:13 is closely linked to the last phrase of 2:12, and introduces the second significant metaphor of Israel's and/or Judah's salvation, namely, the breach maker-king. The development of the pastoral metaphor, which depicts Yahweh as the shepherd in Micah 2:12, recedes to the background and in Micah 2:13, the associated less figurative depiction of Yahweh's rule, and especially his powerful, commanding, military and victorious leadership, in the ideal future, comes to the pole position (Ben Zvi 2000:67). According to Andersen and Freedman (2000:340), the roles are not incompatible, because a king at least could be addressed as a shepherd, and a shepherd could turn out to be a king, a prophet or a lawgiver. The great multitude of people who are gathered within the fold, are here released from the pen and march out, with Yahweh as their leader (Hillers 1984:39).

The verb that is used in the title ascribed to Yahweh, and the reference to the gate, has led to varying speculations (cf. Ben Zvi 2000:67; Mays 1976:75). The verb פָּ [break out/through] is mostly used to describe breaking through or down walls (cf. Neh 1:3; Pr 25:28), in the context of resistance, and this is unnecessary for defenders. The combination of the verb יָָָ [go through, come out, exit] with [gate] typically describes an army going out on a campaign (cf. Mi 1:3) (Andersen \& Freedman 2000:340). Whilst the text is silent about the major problem (i.e. an exact description of events of $701 \mathrm{BCE})$, the picture may precede Micah 2:12 and explain how the people have been regathered. The unique, definite title הָפריץ suggests the outlandish and unpredictable demonstration of Yahweh's power, occasionally referred to

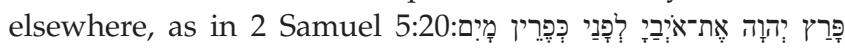
[The LORD has broken through my enemies before me like the breakthrough of waters, NASB] (Hillers 1984:39). Jenson (2008) remarks that:

The language used is that of the Exodus and highlights that Israel's hope lies in the character of the God who brought them up from Egypt. The Israelites go up ... from Egypt (Ex 13:18) because God goes before his people (Ex 13:21; Nm 27:17; cf. Is 52:12) and passes over before them (Dt 31:3). The escape from oppression at the Exodus is a powerful paradigm of the return from exile (Hs 11; Is 11:16). (p. 130)

Whilst the language suggests that Yahweh assumes a leadership role, creating the path, or breaking the enclosed wall, and the troops or sheep following, in its present context, Micah virtualises a future when Yahweh's grace will break through any obstacles no matter how formidable and insurmountable, and lead his people to triumph and freedom without restraints (Dempster 2017:103; Hillers 1984:39).

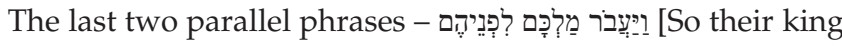

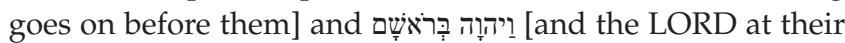
head] - describe the intensification of the most important feature of liberation, recovery, renewal and triumphal procession of Yahweh's people. Dempster (2017) in his summary of the parallelism of 'king' and 'LORD' in the last two phrases notes that:

\footnotetext{
... [T] his image suits the context as Yahweh is viewed as a shepherd-king, a common symbol in the ancient world. Israel has had plenty of leaders, but they have been abysmal failures ... These leaders were terrible shepherds who not only neglected their flocks, but [also] became parasites, leeches, and ... even cannibals. Now Yahweh finally addresses this situation and becomes their Good Shepherd who tenderly gathers his people and sets them free from their prison of exile (cf. Is 40:11). (p. 103)
}

Interpreted in this manner, Micah 2:13 simply amplifies the salvation oracle of 2:12 in which Yahweh's sovereignty is 
manifested in the gathering of the population of his people. Consequently, the promise of recovery and renewal in the final form of this unit (Mi 2:12-13) fits very well with the prophetic view of Yahweh's plan for Israel - of his compassion for an injured nation, one that enjoys Yahweh's favour.

\section{Ethical models for reversing oppression in leadership praxis}

One of the essential drives of this article is the attempt to use Micah's metaphor of shepherd-king and his flock (Mi 2:12-13), as an ethical model for reversing oppressive leadership praxis, in the readers' socio-economic and religious context. However, before evaluating Micah's shepherd-king model of leadership, two brief remarks need to be made regarding ethics and leadership. On the one hand, ethics is a reflective discipline concerning moral character and conduct (Barton 2014:1). Varied scholarly discussions exist regarding the relevance and/or otherwise the applicability of the Bible in contemporary ethical formulation (cf. Arndt 2011:5-7; Avalos 2007:17; Sloane 2008:29-31). Although the significance of the HB/OT ethics for modern communities' reflection may not completely imply sufficiency, in this article, the indispensability and necessity of the descriptive paradigm (cf. Frevel 2015:9-57) will serve as a basis for an inherent prescriptive application of Micah's shepherd-king and flock metaphor. The biblical prophets made oracular proclamations within an ethical society that was obsessed with different and diverse array of theological traditions. They were, possibly having been influenced by such moral context declared prophetic oracles out of the pain and confusion of the Babylonian deportations and the destruction of Jerusalem (Carroll 2012:186-187). The prophets' moral teachings often take the form of condemnation rather than recommendation. Thus, to reconstruct their moral code, one has to look not only at 'what they commended, but at what they condemned' (Barton 2014:36). On the other hand, the phenomenon of leadership in biblical texts connotes different definitions that encompass forms, dimensions and aspects (cf. Pyschny \& Schulz 2018:1-16). In the broadest sense of the term, 'leadership' may be defined as " the power or ability to lead other people", but also more specifically as any way of public guidance, direction, management, stewardship, and governance, including military-political decision making' (Frevel 2018:89).

Generally, Micah oracles imagine actions in a given political, socio-economic and religious context and with a critical, well-crafted understanding of the various ideologies and theology of the past and present. These traditions are constantly being evangelically re-interpreted in view of lived realities, with the goal of presenting imaginative alternatives that are existentially possible. There is no denying the fact that leadership is an essential concern in the Book of Micah. The typology of leadership offices and functionaries, such as judges (ruler and leaders), prophets and priests, is especially hinted at in Micah's oracles (cf. Mi 3:1-12). The prophet's speeches indicate genuine personal confrontation with leaders who appeared to be 'power brokers' of the socio-economic, political and religious establishment of the time (cf. Mi 2:1-5, 6-11). The rhetoric of Micah indicates an intriguing and stimulating perspective on the chain of the relationship found amongst these leaders, their followers/ community, and the circumstances created by their leadership approaches. Whilst the prophetic indictments highlight and connect several aspects of the contemptible catalogue of moral deficiency and decadence which these leaders have established and perpetuated in their society, Micah's eschatological vision of the coming shepherd-king figure (Mi 2:12-13) serves as an intriguing reversal of the leadership praxis. Although Micah's rhetoric may be full of orthodox God-language, his shepherd-king and flock metaphor presents a variety of roles for leadership praxis.

\section{Model of relationship and care}

There is generally a symbiotic relationship between the good, godly shepherds and their sheep. One of the outstanding qualities of good shepherd leaders is their consistent and compassionate caring of their flock (Shelley 2008:132). Such compassionate and affectionate caring treatment is built upon, defined and preserved by a deep sense of a relationship of trust amongst those they lead. The close relationship between the shepherd and the flock ensures that cunning attitudes of predatory wolves are exposed by the consequent outcomes of their viable relationship. The ability to lead is authenticated by the potential to care (Wright 2001:277). As a consequence, godly shepherd leaders must develop a viable atmosphere of a mutually beneficial relationship in communities, institutions or organisations. Because leadership fosters diversity, that is, welcomes and appreciates different perspectives, Micah's shepherd-king model serves as an essential relationship model for leadership. Essentially, what people believe about God fundamentally shapes the way they lead. If God is seen as controlling, capricious or intimidating, as a consequence, those leading or ruling out of that understanding will also behave in controlling, capricious or intimidating manner. Obviously, God is loving and faithful, and this love is primarily and originally lived out in the community (Lidstone 2019:61).

Godly leadership is not the exclusive preserve of strong individuals who create and dominate societies, institutions or organisations to carry out their vision, but a model that teaches people that true leadership happens in relational communities (Lidstone 2019:69-70). The relational leadership model that Micah's shepherd flock offers imagines a setting that allows leaders and individuals to come together in a profound atmosphere of caring, sharing and mutual submission. Such a relational model of leadership guarantees mutual trust, respect and confidence for both the people and the leaders. Relational leaders are responsible leaders in good and inspiring governance who consider themselves as those who are called, chosen or elected to serve (Bromiley 1985:939) and not to oppressively dominate the people. 


\section{Model of protection}

Micah's shepherd-king model does not only serve as an essential relationship model but also as a model for protection of the leaders' subjects. Perhaps one of the most solemn ethical messages of Micah's shepherd-king metaphor for contemporary leaders in their communities or institutions is that of the protection and prevention of abuse of the poor and marginalised through just civil rule and economic policies. Micah specifically notes that economic pressure on the poor occurs with respect to the wealthy urban land magnates forming a private royal connection with the assistance of judicial and government officials of Israel and Judah (cf. Mi 2:2). He verbally describes a cruel confiscation of the economic assets of the poor as manifestly an illegal action of those in power (Noell 2017:191).

The call to leadership entails the development of the potential to shield and protect people from the threat of vulnerability, damage or destruction. Shepherd leaders, who are underperforming with regard to the protection of their subjects, are liable for the damage or destruction caused by predacious wolves. Consequently, shepherd leaders must be proactive to change in the various rapidly changing, challenging and threatening environments and contexts of their people (Resane 2014:4-5; cf. Franklin (2009:412). In view of the fact that good shepherd leaders are human beings who are also undergoing construction, they must constantly see themselves as participants in an eschatological journey with their people (sheep) (Resane 2014:5). Micah's shepherd-king leadership model places an urgent demand on leadership functionaries to reflect on the significance of respecting human life, preventing abuse and protecting the weak and vulnerable in society. The shepherdking metaphor serves as an indictment of Israel's and/or Judah's leadership for their failure of being true shepherds, who are expected to serve, protect and care for Yahweh's people. It invites both individual and corporate reflection. Nogalski (2011) remarks that:

As individuals, we are called to serve others, to act in accordance with calls to justice, and to treat others as we want to be treated. Such behavior obviously precludes the use of force or intimidation to gain personal advantage. It also demands that we critique our own behavior by asking ourselves if we tend to manipulate people or situations for our benefit. (p. 542)

\section{Model of liberation and restoration}

Micah's shepherd-king serves as an inspiring model of liberation and restoration of the fortunes of the oppressed and marginalised. Unlike previous leadership, who had coveted and confiscated property, robbed garments, plundered the house of Jacob and deprived the children of Yahweh's

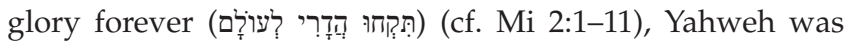
the good shepherd-king who gathered his flock together in their prison house of exile, broke down the prison walls and led his people out to freedom. Whilst previous leaders used their position of power to exploit, oppress and imprison their subjects, Yahweh used his sovereign power to liberate, restore, revive and empower. It is important to note how Micah's shepherd-king metaphor conveys the responsibilities of Israel's leaders who are in sharp contrast with Yahweh, as the true model of leadership. The contrast between Israel's and/or Judah's previous leaders and Yahweh's concerns for divine emancipation and empowerment of his people is very sharp. In Micah's oracles, previous leaders were covetous and oppressive (cf. Mi 2:1-5, 6-11). Judges, prophets and priests were only interested in material prosperity, in their various responsibilities of the administration of justice, and in preaching and teaching of the gospel of the good life (cf. Mi 3:1-12). However, Yahweh decisively and categorically speaks words of truth, with redemptive end (Dempster 2017:104-106). Today, in a deeply rooted cultural default where the pursuit of power in the service of greed, strength and power, success and achievement, entitlement and honour is profoundly entrenched in people's hearts and minds, one can imagine and see the bitter fruit of this in proportionate dimension of covetousness, oppression, pervasive economic exploitation, dysfunction and violence in communities, institutions or organisations, all around the world.

\section{Conclusion}

In all of the ANE, the king was seen as a viceroy of the gods; he was responsible for caring for the affairs of god on earth. As noted in this article, the metaphor of the king as a good shepherd is widespread and makes clear how the role of the king is seen; it is his task to gather, care and graze the sheep and protect them from outside dangers. Employing the dual metaphor of shepherd-king, Micah demonstrated how the failure of leadership caused the demise of the nation - the people were led by covetous and greedy shepherds who exploited and oppressed the people rather than caring for and guiding them. The regrettable situation warranted decisive and emphatic words of truth about the inevitability of judgement. However, at the end of Micah's first major section, the themes of remnant, a good shepherd-king gathering a dispersed flock, and salvation from exile find expression in an eschatological vision of restoration and true leadership with Yahweh, appearing as the head of his people (Dempster 2017:105).

Micah's lamentation of the failure of Israel's leaders within the context of historical and socio-economic realities is sadly and painfully similar to many contemporary contexts, where leaders have failed to live up to the heights of their responsibility. Micah's shepherd-king leadership model in time and context generates an insightful alternative for contemporary leadership praxis, both within the ecclesiological context and society at large. Contemporary leaders at different levels need to critically ask themselves if their leadership is relational or dominating, protective and empowering or oppressive and liberating or enslaving people. Clearly, a conscious reflection on the beautifully harmonised shepherd-king metaphor of Micah 2:12-13 will help to motivate many leaders to create and maintain healthy and dynamic leadership models that will bring significant impact 
not only on their present engagement but also on the future of their communities, institutions or organisations at large.

\section{Acknowledgements}

This article forms part of the author's current research project on 'The nexus between ethics and socio-economic actuality in Micah.' The project is hosted by the chair, Prof. Dr. Christian Frevel, Old Testament Studies, RuhrUniversität Bochum, Germany, with the support of the Alexander von Humboldt Foundation.

\section{Competing interests}

The author has declared that no competing interests exist.

\section{Author's contribution}

I declare that this article is solely conceptualised and written by me.

\section{Ethical consideration}

This article followed all ethical standards for a research without direct contact with human or animal subjects.

\section{Funding information}

This research received no specific grant from any funding agency in the public, commercial or not-for-profit sectors.

\section{Data availability statement}

Data sharing is not applicable to this article as no new data were created or analysed in this study.

\section{Disclaimer}

The views and opinions expressed in this article are those of the author and do not necessarily reflect the official policy or position of any affiliated agency of the author.

\section{References}

Allen, L.C., 1976, The books of Joel, Obadiah, Jonah and Micah, The New Internationa Commentary on the Old Testament, Wm. B. Eerdmans Publishing Co., Grand Rapids, MI.

Andersen, F.I. \& Freedman, D.N., 2000, Micah: A new translation with introduction and commentary, AB 24E, Doubleday, New York, NY.

Arndt, E., 2011, Demanding our attention: The Hebrew Bible as a source for Christian ethics, William B. Eerdmans Publishing Company, Grand Rapids, MI.

Avalos, H., 2007, The end of biblical studies, Prometheus Books, Amherst.

Barton, J., 2014, Ethics in ancient Israel, Oxford University Press, Oxford.

Ben Zvi, E., 2000, Micah, Forms of the Old Testament Literature 21B, Eerdmans, Grand Rapids, MI.

Bosetti, E., 1993, Yahweh shepherd of the people, St. Paul's, Maynooth.

Bromiley, G.W., 1985, Theological dictionary of the New Testament, ed. G. Kittel \& G. Friedrick, W.B. Eerdmans Publishing Company, Grand Rapids, MI.

Carroll, R.D., 2012, 'Ethics', in M.J. Boda \& J.G. McConville (eds.), Dictionary of the Old Testament prophets, pp. 185-193, Inter-Varsity Press, Downers Grove, IL.

Chae, Y.S., 2006, Jesus as the eschatological Davidic shepherd: Studies in the Old Testament, second temple Judaism, and in the Gospel of Matthew, Mohr Siebeck, Tubingen.

Coomber, M.J.M., 2011, 'Caught in the crossfire? Economic injustice and prophetic motivation in Eighth-Century Judah', Biblical Interpretation 19(4-5), 396-432. https://doi.org/10.1163/156851511X595576
Cuffey, K.H., 2015, The literary coherence of the book of Micah: Remnant, restoration and promise, T \&T Clark, Bloomsbury.

Deijl, A.V., 2008, Protest or propaganda: War in the Old Testament book of Kings and in contemporaneous ancient near eastern texts, Studia Semitica Neerlandica 51 Brill, Leiden.

Dempster, S. G., 2017, Micah, The Two Horizons Old Testament Commentary, William B. Eerdmans Publishing Company, Grand Rapids, MI.

Franklin, K., 2009, 'Leading in mission at a higher level: How to become a reflective practitioner in mission leadership', Evangelical Missions Quarterly 45(4), 412-418.

Frevel, C., 2015, 'Orientierung! Grundfragen einer Ethik des Alten Testaments', in C. Frevel (ed.), Mehr als Zehn Worte? Zur Bedeutung des Alten Testaments in ethischen Fragen, pp. 9-57, Quaestiones Disputatae 273, Herder, Freiburg, Verlag, Herder

Frevel, C., 2018, 'Leadership and conflict: Modelling the charisma of Numbers,' in K. Pyschny \& S. Schulz (eds.), Debating authority: Concepts of leadership in the Pentateuch and the former prophets, pp. 89-114, De Gruyter, Berlin, Boston, MA. https://doi.org/10.1515/9783110543391-001

Hillers, D.R., 1984, Micah: A commentary on the book of the prophet Micah, Fortress Press, Philadelphia, PA.

Jenson, P.P., 2008, Obadiah, Jonah, Micah: A theological commentary, LHBOTS 496 T \& T Clark, New York, NY.

Joyce, P., 1998, 'King and messiah in Ezekiel,' in J. Day (ed.), King and Messiah in Israel and the Ancient Near East, pp. 323-337, Sheffield Academic Press, Sheffield.

Kaiser, W.C., Jr., 1998, A History of Israel, Broadman \& Holman, Nashville, TN.

Keil, F.C. \& Delitzsch, F., 1955, Commentary on the Old Testament, Eerdmans, Grand Rapids, MI.

Lidstone, J., 2019, Give up the purple: A call for servant leadership in hierarchical cultures, Langham Global Library, Carlisle, Cumbria.

Mays, J.L., 1976, Micah: A commentary, Old Testament Library series, Westminster Press, Philadelphia, PA.

McKane, W., 1998, Micah: Introduction and commentary, T. \& T. Clark, Edinburgh.

McKeating, H., 1971, The books of Amos, Hosea, Micah, Cambridge University Press, Cambridge.

Mignon, J., 2001, The conceptual coherence of the book of Micah, JSOTSup 322, Sheffield Academic Press, Sheffield.

Noell, E.S., 2017, 'Land grabs, unjust exchange, and bribes: Economic opportunism and the rights of the poor in ancient Israel', Southwester Journal of Theology 59(2), 183-199.

Nogalski, J.D., 2011, The book of the Twelve: Micah-Malachi, Smyth \& Helwys Publishing, Inc., Macon, GA.

Pritchard, B.J., 1795, Ancient near east texts relating to the Old Testament, Princeton UP, Princeton, NJ.

Pyschny, K. \& Schulz, S., 2018, 'Debating authority - Concepts of leadership in the Pentateuch and the former prophets: An introduction', in K. Pyschny \& S. Schulz
(eds.), Debating authority: Concepts of leadership in the Pentateuch and the (eds.), Debating authority: Concepts of leadership in the Pentateuch and the
former prophets, pp. 1-16, De Gruyter, Berlin, Boston, MA. https://doi.org 10.1515/9783110543391-001

Resane, K.T., 2014, 'Leadership for the church: The shepherd model', HTS Teologiese Studies/Theological Studies 70(1), Art. \#2045, 1-6. https://doi.org/10.4102/hts. vtudies/The

Shaw, C.S., 1993, The speeches of Micah: A rhetorical-historical analysis, JSOTSS 145 JSOT Press, Sheffield.

Shelley, B.L., 2008, 'The meaning of Church vocation', in J.D. Berkley (ed.), Leadership handbook of management and administration, pp. 129-141, Baker Books, Grand Rapids, MI.

Sloane, A., 2008, At home in a strange land: Using the Old Testament in Christian ethics, Hendrickson Publishers, Inc., Peabody, MA.

Stewart, R.A., 1996, 'Shepherd', in J.D. Douglas et al. (eds.), New Bible Dictionary, pp. 1092-1093, Inter-Varsity Press, Leicester.

Sweeney, M.A., 1996, Isaiah 1-39 with Introduction to Prophetic Literature, FOTL XV1 Eerdmans, Grand Rapids, Ml.

Sweeney, M.A., 2000, The twelve prophets: Micah, Nahum, Habakkuk, Zephaniah, Haggai, Zechariah, Malachi, Liturgical Press, Berit Olam, Collegeville, PA.

Sweeney, M.A., 2014, Reading prophetic books: Form, intertexuality and reception in the prophetic and post-biblical literature, FAT 89, Mohr Siebeck, Tubingen.

Taylor, H., 1983, Tend my sheep, SPCK, London.

Varhaug, J., 2019, 'The decline of the shepherd metaphor as royal self-expression', Scandinavian Journal of the Old Testament 33(1), 16-23, http://doi.org/10.1080/ 09018328.2019.1599623

Wagenaar, J.A., 2001, Judgement and salvation: The composition and redaction of Micah 2-5, VTSup 85, Brill, Leiden.

Walton, J.H., Matthews, V.H. \& Chavalas, M.W. (eds.), 2000, The IVP Bible background commentary Old Testament, Inter-Varsity Press, Downers Grove, IL.

Westermann, C., 1991, Basic forms of prophetic speech, Transl. H.C. White, Westminster/John Knox Press, Louisville, KY.

Wolff, H.W., 1990, Micah: A commentary, Continental Commentaries, transl. G. Stansell, Augsburg, Minneapolis, MN.

Wright, C.J.H., 2001, The message of Ezekiel: A new heart and a new spirit, InterVarsity Press, Nottingham.

Wright, C.J.H., 2004, Old Testament ethics for the people of God, Inter-Varsity Press, Leicester. 